\title{
Exploiting Shangri-La: Assessing the Tibetan Plateau's Natural Resources and the Work of Karl Wittfogel
}

\author{
Brock Ternes \\ Correspondence: Brock Ternes, PhD (Corresponding Author) SUNY Cortland, Sociology/Anthropology Department, \\ P.O. Box 2000, Cortland, NY 13045, USA
}

Received: November 13, 2019 Accepted: December 7, 2019 Online Published: December 17, 2019

doi:10.5539/res.v12n1p1

URL: https://doi.org/10.5539/res.v12n1p1

\begin{abstract}
This paper applies Karl Wittfogel's theory of hydraulic societies to China's relationship with Tibet. It argues that the Chinese are interested in control over Tibet not only for its land, location, or wealth of natural resources, but also for control of its headwaters. Hundreds of millions of people rely on the numerous large rivers that start in the Tibetan plateau, making the region a critically important water supply for Asia. Wittfogel's work theorizes that China's territory and authority has expanded with the need to secure water for its large population and food production. The paper contains two sections: the first summarizes Wittfogel's arguments, a history of Tibet, and China's control of it; the second describes China's attempts to modernize Tibet, specifically through river development, and the environmental damage caused by such efforts. Tibet's rivers are crucial for the entirety of Asia, and the Plateau's massive supplies of water are just one of its many resources. By focusing on rivers, this article describes the importance of Tibet and how increasing levels of resource extraction legitimatize Chinese centralized authority.
\end{abstract}

Keywords: river development, natural resources, Karl Wittfogel, critical theory

"If water is the essential ingredient of life, then water supply is the essential ingredient of civilization." David Sedlak, Water 4.0 (2014, p. 1).

\section{Introduction}

Freshwater scarcity has become a growing concern in Asia, where drought and desertification have jeopardized large swaths of the continent. Extreme climate shifts have stressed water supplies across the continent, leaving its ecosystems and societies struggling to secure sufficient supplies of water. In an attempt to augment its water supplies, the Chinese have advanced a decades-long operation of river modification which includes some of the world's largest dams, channels, and reservoirs. To understand how surface water in Asia has been stressed by these construction projects, this paper applies the work of the critical theorist Karl Wittfogel to Sino-Tibetan relations. Tibetian headwaters feed several rivers on which hundreds of millions of people rely, and China's investment in grandiose hydro-projects in the region lends credence to Wittfogel's notion of "hydraulic societies." Rivers and societies comprise an interconnected socio-ecological system, and understanding China's efforts to access and manipulate the most in-demand rivers in Asia can provide insight into the relevance of critical theory in the context of environmental degradation and resource depletion.

Arguably no nation on earth has fought as hard to secure its water as China, and Wittfogel's work offers important insight while explaining China's drive to control the waters stemming from the Plateau. Asia as a whole contains large desiccated landscapes and has a relative disadvantage compared to other continents: it has to provide water for two-thirds of the world's population with only a third of its runoff, " 80 percent of which is concentrated in the short monsoon season" (Pearce, 2006, p. 22). The challenges of slaking China's thirst derive in part from the uneven distribution of water within the country. Southern China (which is generally defined as the area of Yangtze River basin, and territory to the south) holds four-fifths of China's available freshwater and has roughly half of China's population. The North China Plain is much more water-stressed and suffers the severest shortages; it has 45 percent of the population, two-thirds of the farmland, and only one-fifth of the nation's water (Bochuan, 1991; Liu, 2002). China now has over a dozen megacities, each with at least 10 million inhabitants, and nearly half of China's 600 largest cities are projected to face severe water shortages (Gall, 2015).

As a result of this placement of settlements and farms, cities in the arid north like Beijing are rapidly exploiting their groundwater. Rural and urban water usage are in rife competition, as the water needed by rural communities has been diverted to the ever-growing megacity Beijing. Beijing's expanding suburbs now boast over 40,000 wells, which supply two-thirds of the city's water, but excessive groundwater withdrawals have led to land subsidence and fractured pipes 


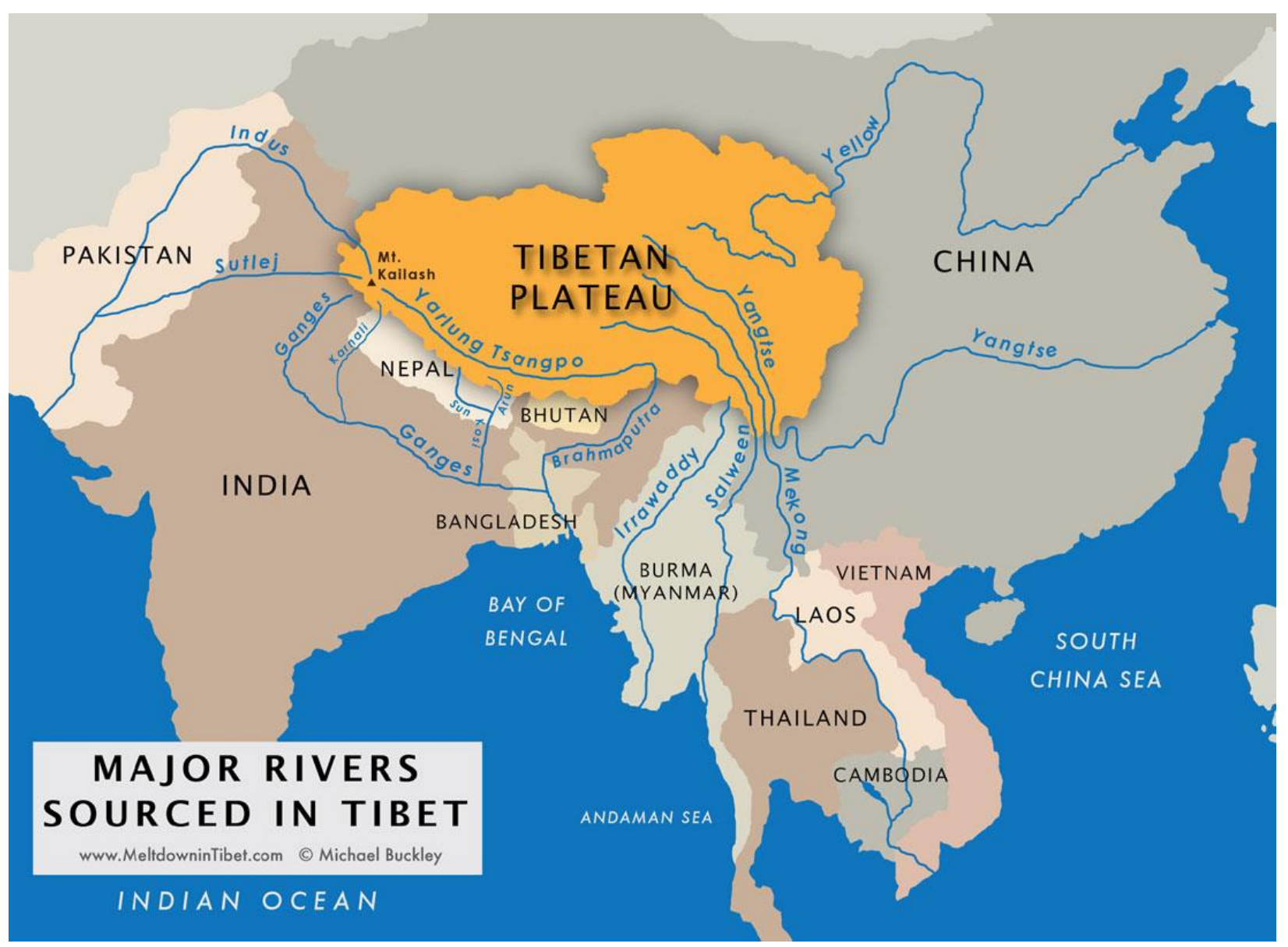

Figure 1. Map of Rivers Originating in the Tibetan Plateau

Source: Buckley (2015)

around Beijing (Gall, 2015). Due to its reliance on wells, the water table below the capital has dropped over one meter a year since 1950 - a deletion so large that Beijing itself sinks roughly ten inches annually (Ma \& Changming, 1985; Postel, $1984 ; 1985)$. Worse yet, as rivers are overdeveloped, other adjacent sources of surface water like lakes and reservoirs are being excessively exploited and polluted (Kira, 1998). Northern China, incidentally, has experienced years of below-average rainfall, a quarter of its forests disappeared from 1960 to 1990, and desertification has been on the rise for decades - over one-seventh of China is now desert (Bochuan, 1991). This wave of ecological decline further accelerates the exhaustion of Beijing's groundwater.

Geographically, China contains a clear mismatch regarding the distribution of water, people, and farmland. Tibet's massive (albeit distant) rivers are obvious water supplies that could facilitate China's endurance against drought, desertification, receding aquifers, and water shortages. Nine of Asia's largest rivers-including the Brahmaputra, Ganges, Indus, Mekong, Yangtze, and Yellow — are fed by the meltwaters of Tibet. The Plateau is known as the "water tower of Asia" for good reason: the collective river system of the Ganges, Brahmaputra, and Meghna has a catchment area that spreads through five nations and its basin is home to roughly 700 million people (Brichieri-Colombi, 2009, p. 15). Each spring, the glaciers of the Himalayans give life to a series of some of the most in-demand rivers on the planet. With the exception of the glacial collections at the poles, these glaciers represent the largest volumes of ice in the world.

Like the North and South poles, Tibet's glaciers are remarkably sensitive to even the slightest fluctuations in temperature, and the glaciers' high altitude exposes them to more rapid rates of warming than other parts of Asia. As global warming intensifies, these icecaps will release an excess of meltwater in the coming decades (Chellaney, 2011; Immerzeel, van Beek, \& Bierkens, 2010; Zhao \& Schell, 2008). Projections warn that global warming will cause between one-third and two-thirds of the region's 56,000 glaciers to vanish by 2100 (Wester, Mishra, Mukherji, \& Shrestha, 2019), and without mitigating efforts, a billion souls across Asia could face critical water shortages by 2050 (Fant, Schlosser, Gao, Strzepek, \& Reilly, 2016). Regional observations indicate that Himalayan glaciers melted twice as fast over the years 2000 to 2016 as they did from 1975 to 2000 (Maurer, Schaefer, Rupper, \& Corley, 2019); if the world's roof continues to leak at its current pace, the nearly 1.9 billion South Asians who rely on glacier water will face extreme water shortages by the end of 
the century. Combined, China and India have over a third of the world's population and only 10 percent of its freshwater (Black, 2004), implying that any freshwater losses would trigger intense competition.

While the Chinese economy has been expanding at a breakneck pace (not to mention the booms of the Indian, Korean, and Japanese markets), these bursts have not been without consequence. Asia's collective economies have been in a stage of hypergrowth that has contributed to the destabilization of ecosystems all across the continent. Unfortunately, economic growth has been the primary objective of the Chinese government, ironically, since the Communists took over. Mao Zedong called not just for a war on nature but also for a booming economy, regardless of the ecological meltdowns it created. In 1949, he said:

The pace of China's economic development will not be slow, but may rather be quite rapid. A prosperous China is well within sight, and there is no foundation for pessimism about China's economic revival (in Bochuan, 1991, p. 139).

Since the Mao era, China's economic explosion has resulted in resource extraction, especially in the Tibetan region. Mao proposed borrowing water from the south for northern China's consumption, and the Chinese have obliged his hope throughout their contemporary economic boom. Mao, and his contemporaries, “...developed a keen interest in hydraulic engineering and made water resource management a priority upon taking power" (Moore, 2018, p. 167). The price China and its riparian neighbors pay for their economic development is environmental deterioration, and this article applies the work of Karl Wittfogel to buttress the case that Mao's war on nature has not waned, but intensified. These crises within water cycles are reminders that economic growth often comes at enormous environmental costs.

The manuscript is organized into the following sections: first, I briefly summarize Wittfogel's contributions on authority and water management, and touch on the history of the ownership of Tibet. I then turn to China's more recent attempts to control Tibet's headwaters and the ecological destruction resulting from such development. Following that, I provide a critique of the hydrocracy, a class of rulers responsible for conceiving extensive river manipulation. By way of conclusion, I suggest that these massive undertakings signal the formation of a hydraulic state, a configuration of authority that ultimately damages the continent's ability to draw from Tibet's rivers.

\section{Wittfogel and Hydraulic Societies}

Karl Wittfogel contended that bureaucratic states and advanced irrigation systems supported each other, while theorizing that early irrigation civilizations (specifically in China, but also in Peru, Mesoamerica, and elsewhere) developed for fundamentally the same reasons: the establishment of centralized water supplies. These groups' parallel evolutions pivoted around control of water sources, forming the characteristics of his "hydraulic society" or "hydraulic state" (Wittfogel, 1938). Hydraulic societies can be defined as those with "hydraulic constructions that... are managed by an inordinately strong government..." with a state government that "is operated by a substantial number of full-time specialists" (Steward, 1955b, p. 66; Wittfogel, 1955, p. 44). For Wittfogel, the ability to manipulate rivers in order to stabilize a water supply is pivotal to the formation of human settlement, and the great empires of history were built on their hydraulic strength. Dams, reservoirs, tanks, and wells are all engineering efforts that reinforce centralized power, and municipal water systems legitimized political centralization and encouraged urbanization.

Wittfogel argued that establishing and maintaining a large-scale irrigation system calls for social reorganization. Wherever the scale of water projects got larger and more elaborate, political power found its way into the hands of a bureaucratic ruling class, thereby forming a hydraulic society. His hydraulic state thesis rested on identifying the commonalities between different civilizations that were associated with the development of complex and large scale irrigation (Beals, 1955). According to Wittfogel, if civilizations are placed in climates without adequate rain or freshwater, they will eventually create a hydraulic society. The emergence of a centralized power structure alongside the assembly of a coordinated irrigation system has been documented all over the world (Steward, 1949; 1955a; Wittfogel, 1955; 1957; Wittfogel \& Goldfrank, 1943; Worster, 1986; 1993). These civilizations share a commonality: the state management of water (specifically for irrigation), and a state monopolization of water provision via a strong central government.

Wittfogel contended that hydraulic states in China emerged because early Chinese civilizations could only maintain an agricultural base in their arid climate that was sufficient enough to feed their population if they used irrigation. Constructing large scale irrigation canals required villages to cooperate and submit to a supra-village authority, leading to a new mode of production (Steward, 1949; Wittfogel, 1957). This mode of production "first arises when waterworks must be undertaken on a larger scale (for purposes of protection and irrigation)" (Wittfogel, 1968, p. 180). In other words, the demands for water made by the state were much higher than the subsistence requirements needed by localized water projects, and the development of water became larger and more urgent. However, a classed relationship emerged as the state needed a growing workforce to create these more advanced water projects: the bureaucratic elite and the laborers. The state bestowed upon itself the responsibility to build larger hydraulic systems and required specialists to organize these projects. In effect, this managerial bureaucracy became the ruling class (Worster, 1986, p. 27). This echelon of 
authority, this emergent class that possessed engineering and riparian knowledge is a class Worster called the "managerial elite," whose authority came from:

the technological control they exercised over the rivers... Better than the peasants, they understood when the river currents would rise and fall, how a ditch could be constructed so it would not silt up with sediment, and what the river gods wanted from humans. This group of rulers, Wittfogel points out, sponsored the first professional studies of hydraulics, astronomy, and mathematics. In fact, much of modern science and engineering has its distant foundations in water-control efforts (1986, pp. 38-39).

Stephen Brichieri-Colombi (2009) uses the term "hydrocracies" to describe the planners, engineers, and water managers within the hydraulic elite. The people who occupy these positions idealize constructing dams, investing in engineering, and exercising mastery over nature are examples of experts who Don Worster (1994) refers to as "constructionists." They include politicians, businessmen, miners, and farmers intent on constructing a region to fit their demands; they are devoted to changing nature through technology and water works projects. These constructionists are responsible for the design and the continuation of the "hydraulic mission," the goal of "exploit[ing] rivers to their maximum potential to meet the needs of society for water supply, energy and food" (Brichieri-Colombi, 2009, p. 8). Previous works outlining this mission suggest that it has been inspired primarily by a centralized government's capacity to engineer and fund the completion of pipelines, channels, dams, and reservoirs (Reisner, 1986). While Brichieri-Colombi (2009) claims this goal has dominated the global north's governments, irrigation departments, and engineering institutions for a majority of the twentieth century, I extend his argument to contemporary China. The Chinese hydraulic elite have more recently become infatuated with the hydraulic mission, and epitomize modern hydraulic society. China has adhered to a constructionist mindset and the hydraulic mission is a top governmental priority.

As their hydraulic responsibilities grew in scope, constructionists have played increasingly important roles in the Chinese government. Control of water supplies represents the ability to augment economic growth, a reality brought to life when one considers that former engineers have recently dominated the China's political ranks. When localities, states, and nations of all sizes can obtain sufficient water, they can complete an assortment of growth-related tasks: agricultural, industrial, or municipal expansions. Water is not only indispensable but also highly functional - it is a means to any number of economic ends. As a basis for life, water is an "axis resource," one that underlies all others (Prud'Homme, 2011). As such, its management has been of tremendous importance in Chinese policymaking. In fact, Hu Jintao, China's former president, is a trained hydroengineer who once worked for Sinohydro, the largest dam building company in the world. The company has constructed dams generating 70 percent of China's hydroelectric power, the world's tallest dam (Xiaowan), and many of the most controversial dams on the planet that have generated significant anti-dam activism (see Mertha, 2008; Watts, 2010). Former President Hu is arguably one of the most powerful members of the hydraulic elite in the world, and his nation's hydraulic mission enabled him to oversee some of history's grandest water projects simultaneously.

Wittfogel analyzed how Chinese authority evolved and how it was influenced by water management. Planning waterworks is critically important for the arid nation struggling to feed its massive population. Under Wittfogel's theory of hydraulic civilizations, China's territory has been influenced by surrounding water sources - specifically those of Tibet. Political control over the massive Plateau grants China access to Tibet's natural resources. Factors including elevation, distance, and unstable terrain make Tibet's resources challenging to extract, a conversation I cover in the second half of this article. The Tibetan Plateau has a long history of territorial disputes, and control of Tibet has a complicated and often-contested past, a point to which I now turn.

A central reason for China's resolve to keep Tibet is the region's wealth of minerals, energy, and water. After the Chinese communist party came to power in 1949, Tibet soon came under Han Chinese rule. Mao Zedong's attempts to claim Tibet in the name of China began on October 7, 1950 and the plateau was annexed by 1951 (Mitter, 1964). An incredible addition in terms of size, resources, and political positioning, the Plateau gave China a border with India and Nepal and control over parts of the Himalayas. Nearly a decade after Tibet's annexation, China and India started a month-long battle in the Himalayas known as the Sino-Indian war of 1962. This was sparked by border disputes along the "McMahon Line" (the border of Tibet and India along the Himalayas), and the Tibetan uprising in the late 1950s. The short war ended when Chinese forces left the disputed area and claimed a ceasefire, though the plateau remains a divisive issue in Chinese-Indian relations (Chellaney, 2011; Dapondes, 1968; Hodum, 2007). After being incorporated, in 1965 it became China's latest "autonomous region," a land of ethnic minorities, when combined, comprise 60 percent of China's territory (Chellaney, 2011). China has used its guardianship to claim access to important rivers originating in Tibet, made evident by the insistent development of not just on the Tibetan Plateau, but also of the rivers themselves. 
In order to fuel its expansion, China has invested heavily in extraction operations in the resource-rich land it calls "the western treasure house" for the past seventy years. The completion of People's Liberation Army's road from Golmud on the northern edge of the plateau to Lhasa in south-central Tibet in 1954 exposed the Plateau's people and resources to Chinese influences and demands. Virtually no development took place in Tibet until it became the Tibetan Autonomous Region (TAR) and the Communists began construction. Many modernizing projects, including several tall hydropower dams, canals, roads, and trains have rolled over the Tibetan landscape starting in the 1950s. Since then, the Plateau's fragile ecosystems have suffered and species' migration streams have been rerouted if not altogether cut off. Evidence suggests that the Chinese have not only overexploited Tibet and damaged its ecosystems, but environmental exploitation has expanded into China proper as well (Economy, 2005; Hughes, 2006). In order to depict how rapidly the Plateau has been breached, I must describe the construction of some of China's most ambitious water projects.

\section{Constructionists Eye the Tibetan Autonomous Region}

Mao Zedong's impressive road to Lhasa was indicative of a massive investment in modernizing projects all over China's territory, which rose to an almost incomprehensible level in the late 1950s. As the Chinese embarked on Mao's "Great Leap Forward," they nearly doubled their annual investment in construction by 1958 , the same year they doubled the amount of earth they moved for hydroprojects over the past decade (Bochuan, 1991; Watts, 2010). Since then, "China has built more dams than the rest of the world combined" (Chellaney, 2011, p. 157). Forty-six percent of the world's large dams are in China, and nearly all of them have been built since the Mao era (Postel \& Richter, 2003, p. 16).

And the changes implemented by the hydraulic elite have been as rapid as they are gargantuan. China's Great South-North Water Transfer Project, or the South-North Water Diversion Project, (SNWD) is likely the most ambitious embodiment of the hydraulic mission ever attempted. While China is well-known for its gigantic hydropower and irrigation dams, this megaproject also functions as a means of transference of Tibetan river waters towards the arid North. It was first conceived in the Mao-era's "Great Leap Forward," but was finally approved by the State Council in 2002 and began construction in the spring of 2003. The project is a collection of three routes or legs, the first of which was completed in 2014; this diversion has started to send approximately 39 million acre-feet (12.7 trillion gallons, or roughly four times the annual flow of the Colorado River) annually from the Yangtze River basin to the North China Plain. The SNWD Project, however, has been plagued by a number of delays, cost overruns, and deadline revisions. Citizens of Beijing were told they would be drinking the waters of the Yangtze by 2007 (Pearce, 2006; Watts, 2010); the original estimate of the project was $\$ 15$ billion, but updated appraisals place the cost of the transfer more than $\$ 62$ billion (The Economist, 2014a). Planners of the SNWD Project say it will be complete within 20 years, but other estimates suggest that this diversion will take closer to 35 to 40 years of non-stop construction (Chellaney, 2011; Pearce, 2006). This is not unusual in the world of water infrastructure, as Sandra Postel (2017) notes:

It's tempting to try to solve these problems with bigger versions of familiar twentieth-century projects - especially larger dams and longer water transfers...Besides high capital costs, big engineering schemes are notorious for delays, cost overruns, and hidden social and environmental damages. Three-quarters of large dam projects end up costing nearly double the original estimate. If planners had used these actual costs in their original project analysis, many dams would be deemed economically unviable (p. 13).

Overall, SNWD aims to steer Tibet's rivers towards the North China Plain. The second channel specifically attempts to redirect the Yangtze into the Yellow River, 65 miles away. For decades, the Yellow River has been overused. Like the Yangtze, the Yellow also begins in Tibet, and along its 3,000-mile journey to the Yellow Sea roughly 500 million people rely on it for drinking and irrigation water; it also supports most of China's wheat production and nearly half its coal production (Moore, 2018). The surrounding provinces of the Yellow River have water requirements that far exceed what the river can offer; although the government insists its "Mother River" will never dry up, it has now slowed to a trickle 80 miles before it reaches the sea (Postel, 2017). The ambition of Yellow River development is clearly outlined in Chinese historical planning: “...we wanted to conquer the Yellow, and transform the Yellow Basin's natural condition.... In order to satisfy with Yellow River resources the demands of socialist construction and the coming Communist transformation of the national economy" (Weiyuanhui, 1991, p. 121).

Even if this grandiose scheme is successfully completed, the diversion of the Yangtze is still unlikely to meet all of the demands of China's North Plain (Postel, 1989). This large supply-side project is indicative of two important themes surrounding hydrocracies: the tremendous environmental tolls the Chinese government has been willing to pay since the time of Mao, and the enormous drive to sustain economic growth, particularly agricultural output in the drought-stricken north (O’Lear, Briggs, \& Denning, 2013). The ambitious second, northward leg of the SNWD transfer will supply about a third of Beijing's annual demand, and an even greater proportion of Tianjin's (The Economist, 2014a). But the expansion of cities, farms, and industry will increase the water required in northern China, even if 
conservation efforts are widely implemented. Compounding the problem is the Maoist obsession with agricultural self-sufficiency, as nearly 70 percent of water used in the north is used for agriculture (The Economist, 2014b). If further thirsty development and growth is temporarily supported by the transfer project, it might ultimately exacerbate water scarcity in the north. Contrary to the beliefs of the hydrocracy, increasing supply fails to address the root of the nation's problem: high water demands and inefficient use. Solving water accessibility issues requires more management, not more transfers, and management is crucial to solving a water crisis that threatens the Chinese countryside's development and stability.

The SNWD Project is shrouded in controversy, but its most contentious component is also China's most controversial dam: Three Gorges. Completed in 2006, this massive \$30 billion impoundment of the Yangtze River is nearly 600 feet high and one and a half miles long. Three Gorges has been responsible for massive levels of pollution, displacement, and depletion of the rivershed, and has therefore faced intense opposition. The creation of its colossal reservoir has totally changed the landscape, and thousands of cubic kilometers of water from the Yangtze are lost annually through the evaporation of water trapped in its reservoir (Chellaney, 2011). Due to sediment changes resulting from this construction, the Yangtze has recently become so polluted it is now the largest source of pollution of the Pacific Ocean (Wong, 2010). Additionally, the dam's construction displaced nearly 1.4 million people - although such environmental tragedies and relocations do not discourage China's managerial elite, whose hydroprojects have displaced 23 million people since the Mao Era (Chellaney, 2011).

Experts worry that China's growing water demands will compel "Chinese engineers [to] devise new ways of geoengineering in the Himalayas to prove themselves" (Rafferty, 2010), and the projects have continued to alter the landscape across Asia. In the southeastern slopes of the Himalayas, China built one of its largest dams on the Min River, the Zipingpu dam. Prior to its construction, the scientific community considered the site of the Zipingpu to be unsafe because it rests on a major fault line. But building continued as planned, and the dam was operational by 2006. Unfortunately, two years later a magnitude- 8 earthquake was triggered by the weight of the dam's reservoir, a phenomenon called "reservoir-induced seismicity" (Watts, 2010, p. 61). A year after the disaster, the Chinese fearlessly announced that they would continue to build twenty additional plants on the Yangtze, many of which are close to fault lines. Amid these concerns, a growing number of China's water users now express sincere nervousness that "China's largely centralized, technobureaucratic approach to river basin management has proven increasingly incapable of preventing and resolving interjurisdictional conflict over shared water resources" (Moore, 2018, p. 162).

Despite these numerous engineering accomplishments and gargantuan investments in water-which reveal the sheer determination of the constructionists - China still faces alarming water shortages. The Chinese hydraulic elite struggle with major management and efficiency issues, foremost among them is pollution. One would imagine that the enormous city of Beijing, located in the arid north, would protect its nearby sources of groundwater, but its aquifers have been contaminated by industrial wastewater and sewage dumped into the city's waterways (Bochuan, 1991; Chellaney, 2011). If China developed a more rationalized distribution and selection of crops and relied on dryland or rainfed farming (growing food without irrigation and only using climatic conditions and precipitation) the unsustainable use of irrigation water obtained from surface and groundwater supplies could be avoided. Currently, however, that goal is very far from reality, as "88 percent [of the total volume of water used in China] is used for agriculture" (Bochuan, 1991, p. 36). Irrigation practices also suffer from wastefulness; the estimates measuring the efficiency of irrigation systems ranges from 37 to 50 percent, meaning that at least half of the water extracted for watering crops fails to reach the fields (Postel, 1985, 1989; Xu, 2001; Wang, Xu, Huang, \& Rozelle, 2005; Xie, 2009). Poor farming practices also contribute to soil salinization and degradation, a serious problem for the Chinese (Brown, Flavin, \& Postel, 1991). As Charles Fishman (2011) states in The Big Thirst, "There is no leapfrogging over an aging water system" (p. 260). The hydraulic elite could attend to some of the most important shortcomings within the designs of their projects. Clearly, ignoring environmental protections, and problems of mismanagement and inefficiencies, will be jeopardize China's hydrologic missions no matter how many rivers they dam or aquifers they drain.

For all of the waterworks the Chinese have embarked upon since the mid-twentieth century, its hydraulic mission still faces many challenges. Don Worster's Rivers of Empire (1986) introduced the notion of a "hydraulic trap," a syndrome of engineering promises to solve all problems of water scarcity, but policies and technologies often fail to meet these challenges, "technological dominance over nature became an obstacle to new possibilities... Today that sense of being trapped by our own inventions pervades industrial societies everywhere" (p. 329). These challenges imply that if China's hydraulic elite took water management into greater consideration, and if they addressed the inefficiencies of their water projects, they would not have to invest nearly as much in water development. Perhaps the very nature of constructionism is to ignore the root causes of water scarcity-such as unsustainable agricultural and industrial practices in the arid north - and promote the manipulation of the rivers via technological mastery over nature.

These massive water projects illustrate China's eagerness to dictate the flow of rivers, but other noteworthy 
constructionist developments along China's side of the Himalayas have recently been completed. The Chinese investment in general infrastructure (including roads, electrical grids, telecommunications, and railways) on the Plateau totaled \$46 billion over the decade of 2000-2009 (Chellaney, 2011). Arguably the most impressive non-hydraulic investment made in Tibet has been China's Golmud-Lhasa railway (also known as the Sky Train or the Qinghai-Tibet railway), which was completed in 2006, the same year as the Three Gorges and the Zipingpu dams. On the Plateau's eastern side lies the Kunlun mountain range, an area so unforgiving it was viewed in previous decades as virtually impassable (Theroux, 1988). Its permafrost and layers of ice, which expanded and melted according to the seasons, made laying tracks almost out of the question. Determined to overcome any obstacle, China's railroad engineers have designed a system to pump cooling agents into the ground surrounding the railway so it stays frozen, a practice that leads eyewitnesses to believe that the "...railway [is] going to be even harder to maintain than it had been to build" (Watts, 2010, p. 37).

Given the remarkably challenging terrain, developers are aware that traversing across the Plateau via airplane would be distinctly advantageous. In 2013, the Daocheng Yading airport was opened in Tibet, with an altitude of 14,470 feet and a \$258 million price tag (Mutzabaugh, 2013). Daocheng Yading is now the highest civilian airport in the world, beating out another airport in the Tibet Autonomous Region, Bangda. Not to be outdone, a third airport located in northern Tibet is now under development, and it will be the highest airport on the planet when it opens in Nagqu at an elevation of 14,550 feet. These three most elevated airports on earth are hailed as modern conveniences that slash travel times (which typically took days by automobile) but they come at great expense: transportation projects in the TAR cost a total of $\$ 3.5$ billion in 2013.

Suffice it to say, the airports and train lines allow Chinese officials to extend their reach into Tibet. These projects illustrate China's broader desire to control Tibet, conquer the Plateau's harsh biophysical restrictions, and master and redesign nature. Moreover, the incredible amount of work, resources, and money put into such projects are testaments to the stock of resources the Plateau contains. Such investments have facilitated the exploitation of Tibet's water, mineral, and lumber resources. Water is just one of Tibet's valuable resources, and a plethora of copper, iron, lithium, lead, and gold reserves - along with 120 different minerals - are now a train ride away for Chinese mining companies (Chellaney, 2011). Extracting these resources was not cost-feasible when roads were the only way to reach them, but "...minerals became easier to exploit as the Sky Train cut freight charges by 75 percent" (Watts, 2010, p. 38). Exploring the Plateau is now potentially more profitable as its land becomes increasingly reachable, and resource extraction shows no signs of slowing. Examining the history of timber extraction alone provides a sense of the depletion: estimates suggest that the Plateau lost three-quarters of its forests since 1959 (Chellaney, 2011). Although the government began to restrict logging in the late 1990s, the logging industry has continued apace, clearing 50 times the permitted limit (Watts, 2010). Furthermore, the forests of Yunnan, just east of Tibet, are being stripped bare for its Mutsutake pine mushrooms-for which there is a lucrative foreign market. The immense resources of Tibet are obviously prized, and China has positioned itself for unprecedented levels of extraction.

As if vast quantities of natural capital did not make the Plateau valuable enough for China, the Chinese have squeezed money from Tibet by evoking the utopian superlative "Shangri-La," an ideal from James Hilton's novel Lost Horizon (1933) to attract Western, paradise-seeking tourists. Made possible by the tremendous investment in transportation construction, the once-isolated region is now exposed to Chinese and Western tourists and several sites of Chinese industry. The allure of Shangri-La has facilitated rapid development and resource extraction in Tibet. One of the keys to the Plateau's attractiveness was its remoteness, and becoming more accessible and more visited damages its wonderland appeal.

These connections with foreign influence have not only changed the landscape, but also the culture of Tibet. The relations of native Tibetans with outsiders have resulted in a westernized Tibet, yet despite the ecological destruction of the Tibetan homeland, the Chinese (and tourists') presence in Tibet has not been met with much hostility. Tibetan standards of living are showing a slight improvement, and wages have been increasing. These outcomes have resulted in a rise of ambivalence among the locals regarding their views of modern materialism; one Tibetan expressed ambivalence about the change of pace on the Plateau: "Overall, I think it is a good thing because this area is poor and isolated so people need more economic development. But it is bad for the environment" (Watts, 2010, p. 32). That point of view is in stark contrast with the popular attitudes of Tibetans a generation ago, who were outraged at the first signs of development. This region was sheltered from consumer culture and advanced capitalism, but those forces have worked quickly and successfully to change the hearts and minds of the residents. After the completion of Mao Zedong's road, the first cars, phones, and televisions appeared. Then tourists, whose business gave some Tibetan families their first incomes, signaled a new economic opportunity. A major transformation has emerged on the plateau: locals tolerate the surrounding environmental destruction, leave behind traditional life, and risk compromising their Tibetan identity. 


\section{Conclusions}

Transformation has been a thematic continuity in this article. The process of Tibetan Sinicization ushered in a loss of Tibetan resource protection. China has embarked on a hydraulic mission (or more generally, an excavation or exploitation mission) every bit as intense and ambitious as the Bureau of Reclamation's was in the United States in the mid-twentieth century, incorporating not just water supplies but all available resources. To further complicate the environmental issues of Tibet (and the rest of the continent) China is not the only nation in Asia looking to its hydrocracy to secure water supplies for its people, and China's neighbors are designing their own intrinsically motivated hydroprojects as well. In 2009, South Korea began work on its very expensive "Four-Rivers Project," which aims to straighten and change the course of its rivers (Chellaney, 2011). Moreover, China's main competitor for Tibet's waters, India, has invested in large-dam construction in the previous decade. India's \$140 billion Interlinking Rivers Project aims to expand irrigation through the construction of 5,600 miles of canals connecting 37 rivers, transferring the waters of its monsoon rivers (the Ganges and the Brahmaputra) in the north to its arid southwest (Postel, 2017). If that plan is executed, "It is at least possible that within two decades, the two most populous countries in the world - with the two fastest-growing economies - will have spent a quarter of a trillion dollars on redirecting their rivers and remaking their hydrology" (Pearce, 2006, pp. 223-24).

Even with that enormous price tag, perhaps the severest costs these nations face will be environmental, not monetary. The Tibetan Plateau is being exploited for the first time in history, and Shangri-La no longer exists. Tourists will not be able to find it - as they enter Zhongdian they are welcomed by noisy construction sites and denuded mountains (Watts, 2010, p. 15). The penetration of this once majestic and remote highland has weakened its ecological stability through unchecked deforestation and grassland degradation. As for its rivers, Tibet's are now arguably the most sought-after on the planet.

And these rivers reveal an important, reoccurring pattern in history. Societies the world over and through the centuries have relied on rivers, and this reliance has changed how people organize themselves. According to Wittfogel, the emergence of hydraulic bureaucracies has been culturally pervasive since the agricultural revolution. But rivers also reveal the lengths authorities are willing to go to command water. The mastery of nature has been an incredible motivator for those seeking power. Over 3,000 years ago in China, emperors of the Zhou dynasty "were judged by their ability to control the environment as well as the people.... Controlling rivers was central to ruling the population" (Watts, 2010, p. 45). Flood control and water resource policy have underlain government functions for millennia in China (Chi, 1963). Mao Zedong used water to change the direction of China; he placed it at the center of his Great Leap Forward and considered water to be a critical component of China's economic future. The leitmotif of Wittfogel's contributions in this paper is that water is power (it is not coincidental that China's former president has a sophisticated understanding of how water can be controlled).

Just how far are some Chinese willing to go to access Tibet's rivers? China plans to build the world's largest dam and hydropower station on the Brahmaputra River, a megaproject that "will by itself produce the equivalent of three-quarters of the total capacity Australia had in 2010" (Chellaney, 2011, p. 132). Besides investing in hydropower and irrigation projects, China's hydraulic elite are most concerned about water transfer projects—and not just diverting water for energy or irrigation, but "pushing rivers around," off their natural flows and towards its most water-scarce regions, just as American engineers attempted during their hydraulic mission of the middle-twentieth century (Worster, 1993, p. 135). Constructionists have also eyed the Mekong River, the 2,800-mile long river that starts in the Tibetan ice fields and empties into the Vietnamese delta. It has been called the "least modified of all the major rivers in the world," (Pearce, 2006, p. 96) a title that it will inevitably lose. One prominent member of China's Mao-era hydrocracy even suggested redrawing the paths of Tibet's rivers by detonating 200 nuclear warheads in the Himalayas to create a 2-kilometer wide tunnel that would shift Brahmaputra River northward towards China, preventing it from reaching India (Hodum, 2007). While the idea of moving mountains with nukes was too extreme for the river-moving constructionists, they do not see the act of channeling water from Tibet to the Northern Plains as farfetched. They continue to finance, attempt, and applaud grand acts of mastery, the grandest of these waterworks remains the SNWD project.

This is not simply a trend within Asia; it is a global phenomenon. The number of large dams globally has skyrocketed to approximately 48,000 (Postel \& Richter, 2003), and their length, height, and reservoir size have grown increasingly larger. The worldwide explosion of dam-building has changed the planet in some almost implausible ways. Chao (1995) discovered that the weight of water trapped in dam reservoirs in the northern hemisphere has altered the tilt of the earth's axis and increased the rotation speed of the earth. Large dams can therefore have tremendous environmental consequences in the aggregate, not just individually. To continue Wittfogel's ambitions, future projects could consider water development projects at multiple units of analysis and discussed by a variety of stakeholders. While international cooperation is key to establishing efficient water management virtually all over the world, allocating water resources 
shared by multiple political bodies often resembles a battle more than a negotiation (Chellaney, 2011; Kobori, 1998). This is particularly true regarding Tibetan headwaters. India and Bangladesh, which already have insufficient water supplies, view Chinese exploits as threats to their national security (O'Lear et al., 2013). Nevertheless, if access to natural resources becomes an issue of international competition rather than one of compromise and organization, many millions could face environmental injustices and disenfranchisement if policymakers continue to use technological mastery and deny their neighboring nations freshwater. These interconnected challenges demonstrate how Wittfogel's assessments are lastingly influential.

\section{References}

Beals, R. (1955). Discussion: Symposium on irrigation civilizations. In Irrigation civilizations: A comparative study (53-57). Washington, DC: Pan-American Union.

Black, M. (2004). The No-nonsense guide to water. New York, NY: Verso.

Bochuan, H. (1991). China on the edge: The crisis of ecology and development. San Francisco, CA: China Books and Periodicals, Inc.

Brichieri-Colombi, S. (2009). The world water crisis: The failures of resource management. London: I.B. Tauris.

Brown, L., Flavin, C., \& Postel, S. (1991). Saving the planet: How to shape an environmentally sustainable global economy. New York, NY: W.W. Norton.

Buckley, M. (2015). Major rivers sourced in Tibet. Meltdown in Tibet. Retrieved January 9, 2015 from http://meltdownintibet.com/f_maps.htm

Chao, B. F. (1995). Anthropogenic Impact on Global Geodynamics Due to Reservoir Water Impoundment. Geophysical Research Letters, 22, 3529-3532. https://doi.org/10.1029/95GL02664

Chellaney, B. (2011). Water: Asia's new battleground. Washington, DC: Georgetown University Press. https://doi.org/10.1355/cs34-2j

Chi, C-T. (1963). Key economic areas in Chinese history as revealed in the development of public works for water control. New York, NY: Paragon Books.

Dapondes, A. (1968). The Cuban crises and the Chinese-Indian border war. New York, NY: Vantage Press.

Economy, E. C. (2005). The river runs black: The environmental challenge to China's future. Ithaca, NY: Cornell University Press.

Fant, C. C., Schlosser, A., Gao, X., Strzepek, K., \& Reilly, J. (2016). Projections of water stress based on an ensemble of socioeconomic growth and climate change scenarios: A case study in Asia. PLoS ONE, 11(3), e0150633. https://doi.org/10.1371/journal.pone.0150633

Fishman, C. (2011). The big thirst: The secret life and turbulent future of water. New York, NY: Free Press.

Gall, N. (2015). Why the water is running out. The New York Review, 22, 45-46.

Hilton, J. (1933). Lost horizon. New York, NY: Grosset \& Dunlap.

Hodum, R. (2007). Conflict over the Brahmaputra River between China and India. ICE Case Study 205. Washington, DC: Inventory of Conflict and Environment.

Hughes, P. (2006). Environmental degradation in the Tibetan Autonomous Region. Inventory of Conflict and Environment Case Study. Washington, DC: American University.

Immerzeel, W., van Beek, L., \& Bierkens, M. (2010). Climate change will affect the Asian water towers. Science, 328(5983), 1382-1385. https://doi.org/10.1126/science.1183188

Kira, T. (1998). Major environmental problems in world lakes. In I. Kobori \& M.H. Glantz (Eds.), Central Eurasian water crisis: Caspian, Aral, and Dead Seas (pp.13-24). Tokyo: United Nations University Press.

Kobori, I. (1998). Central Eurasian water perspectives and arid land studies. In I. Kobori \& M.H. Glantz (Eds.), Central Eurasian water crisis: Caspian, Aral, and Dead Seas (pp.7-12). Tokyo: United Nations University Press.

Liu, J. (2002). Study on China's strategy of resources utilization. Beijing: China Agriculture Press.

Ma, L., \& Changming, K. (1985). Water resources development and its environmental impact in Beijing. China Geographer, 12.

Maurer, J. M., Schaefer J. M., Rupper, S., \& Corley, A. (2019). Acceleration of ice loss across the Himalayas over the past 40 years. Science Advances, 5(6), eaav7266. https://doi.org/10.1126/sciadv.aav7266 
Mertha, A. (2008). China's water warriors: Citizen action and policy change. Ithaca, NY: Cornell University Press.

Mitter, J. P. (1964). Betrayal of Tibet. New York: Allied Publishers Private Limited.

Moore, S. M. (2018). Subnational hydropolitics: Conflict, cooperation, and institution-building in shared river basins. New York, NY: Oxford University Press.

Mutzabaugh, B. (2013). Title of 'world's highest' goes to new airport. USA Today, September 18.

O’Lear, S., Briggs, C., \& Denning, G. M. (2013). Environmental security, military planning, and civilian research: The case of water. Environment, 55(5), 3-12. https://doi.org/10.1080/00139157.2013.824327

Pearce, F. (2006). When the rivers run dry: Water-the defining crisis of the twenty-first century. Boston, MA: Beacon Press.

Postel, S. (1984). Water: Rethinking management in an age of scarcity. Washington, DC: Worldwatch Institute.

Postel, S. (1985). Conserving water: The untapped alternative. Washington, DC: Worldwatch Institute.

Postel, S. (1989). Water for agriculture: Facing the limits. Washington, DC: Worldwatch Institute.

Postel, S. (2017). Replenish: The virtuous cycle of water and prosperity. Washington, DC: Island Press. https://doi.org/10.5822/978-1-61091-791-9

Postel, S., \& Richter, B. (2003). Rivers for life: Managing water for people and nature. Washington, DC: Island Press.

Prud'Homme, A. (2011). The ripple effect: The fate of freshwater in the twenty-first century. New York, NY: Scribner.

Rafferty, K. (2010). China's disturbing dam plan. Japan Times. July 14.

Reisner, M. (1986). Cadillac desert: The American West and its disappearing water. New York, NY: Penguin Books.

Sedlak, D. (2014). Water 4.0: The past, present, and future of the world's most vital resource. New Haven, CT: Yale University Press.

Steward, J. (1949). Cultural causality and law: A trial formulation of the development of early civilizations. American Anthropologist, 51, 1-27. https://doi.org/10.1525/aa.1949.51.1.02a00020

Steward, J. (1955a). Introduction: The irrigation civilizations, a symposium on method and result in cross-cultural regularities. In Irrigation Civilizations: A Comparative Study (pp. 1-5). Washington, DC: Pan-American Union.

Steward, J. (1955b). Some implications of the symposium. In Irrigation civilizations: A comparative study (pp. 58-78). Washington, DC: Pan-American Union.

The Economist. (2014a). A canal too far. The Economist, 27, 44-45.

The Economist. (2014b). Grand new canals. The Economist, 27, 45.

Theroux, P. (1988). Riding the iron rooster: By train through China. New York, NY: Putnam.

Wang, J. Z. X., Huang, J., \& Rozelle, S. (2005). Incentives in water management reform: Assessing the effect on water use, production and poverty in the Yellow River Basin. Environment and Development Economics, 10, 769-799. https://doi.org/10.1017/S1355770X05002524

Watts, J. (2010). When a billion Chinese jump: How China will save mankind—or destroy it. New York, NY: Scribner.

Weiyuanhui, H. S. (1991). Huanghe Guihuazhi [History of Yellow River Planning]. Vol. 6. Zhengzhou, China: Henan Renmin Chubanshe [Henan People's Press].

Wester, P., Mishra, A., Mukherji, A., \& Shrestha, A. B. (eds). (2019). The Hindu Kush Himalaya assessment: Mountains, climate change, sustainability and people. Springer International Publishing. https://doi.org/10.1007/978-3-319-92288-1

Wittfogel, K. (1938). Die theorie der Orientalischen Gesellschaft. Zeitschrift fur Sozialforschung 7. https://doi.org/10.5840/zfs193871/250

Wittfogel, K. (1955). Developmental aspects of Hydraulic Societies. In Irrigation Civilizations: A Comparative Study. Washington, DC: Pan-American Union, 43-52.

Wittfogel, K. (1957). Oriental Despotism: A Comparative Study of Total Power. New Haven, CT: Yale University Press. Wittfogel, K. (1968). The theory of Oriental society. Readings in anthropology (2nd ed.). New York, NY.

Wittfogel, K. A., \& Goldfrank, E. S. (1943). Some aspects of Pueblo mythology and society. Journal of American Folklre, 56, 17-30. https://doi.org/10.2307/535911 
Wong, J. L. (2010). The food-energy-water nexus: An integrated approach to understanding China's resource challenges. Harvard Asia Quarterly, Spring.

Worster, D. (1986). Rivers of empire: Water, aridity, and the growth of the American West. New York, NY: Pantheon Books.

Worster, D. (1993). The wealth of nature: Environmental history and the ecological imagination. New York, NY: Oxford University Press.

Worster, D. (1994). An unsettled country: Changing landscapes of the American West. Albuquerque, NM: University of New Mexico Press.

Xie, J. (2009). Addressing China's water scarcity: A synthesis of recommendations for selected water resource management issues. Herndon, VA: World Bank Publications. https://doi.org/10.1596/978-0-8213-7645-4

Xu, Z. (2001). Study on increasing water use efficiency. Journal of China Water Resources, 455, 25-26.

Zhao, M., \& Schell, O. (2008). Tibet: Plateau in peril. World Policy Journal, 25(3), 171. https://doi.org/10.1162/wopj.2008.25.3.171

\section{Copyrights}

Copyright for this article is retained by the author(s), with first publication rights granted to the journal.

This is an open-access article distributed under the terms and conditions of the Creative Commons Attribution license (http://creativecommons.org/licenses/by/4.0/). 